УдК 94(477.64) «ХХ»

DOI https://doi.org/10.26661/zhv-2021-5-57-19

ЗАСАДИ ЗАЛУЧЕННЯ РОБОЧОЇ СИЛИ НА ВІДБУДОВУ МЕТАЛУРГІЙНОГО ЗАВОДУ «ЗАПОРІЖСТАЛЬ У КІНЦІ 40-Х - НА ПОЧАТКУ 50-Х РОКІВ ХХ СТОЛІТТЯ (ЗА ДОКУМЕНТАМИ ВІДОМЧОГО АРХІВУ)

\author{
А. С. Подлужний \\ Запорізький національний університет \\ rjkteam8148@gmail.com \\ ORCID: 0000-0003-4080-601X
}

Ключові слова: чорна металургія, «Запоріжсталь», повоєнна відбудова, промислові робітники, трудове законодавство.
Статтю присвячено висвітленню інформаційного потенціалу матеріалів, які походять 3 відомчого архіву комбінату «Запоріжсталь», датованим кінцем 40-X - початку 50-х років XX ст. Завдяки аналізу актуалізованої поточної документації канцелярії металургійного заводу, та епістолярних матеріалів, було реконструйовано засади комплектування робітниками заводу впродовж першого десятиріччя по завершенні Другої Світової війни, під час відбудови. Розгляд виробничих ситуацій та життєвих колізій на мікро-історичному рівні дозволив відтворити найбільш стандартні прийоми, до яких вдавалося керівництво заводу для залучення та утримання трудових кадрів. Було показано, що вони переважно повторювали загальноприйняті для сталінських часів репресивні практики, поширені від вищого партійного та радянського керівництва УРСР та СРСР до місцевої заводської адміністрації.

\title{
THE PRINCIPLES OF ATTRACTING LABOR FOR THE RECONSTRUCTION OF THE METALLURGICAL PLANT ZAPORIZHSTAL' IN THE LATE 40'S - EARLY 50'S OF THE XX CENTURY (ACCORDING TO DOCUMENTS OF ARCHIVE DEPARTMENT)
}

\section{A. S. Podluzhnyi \\ Zaporizhzhia National University}

Key words: ferrous metallurgy, Zaporizhstal', post-war reconstruction, industrial workers, labor legislation.
The article is devoted to the study of the information potential of the materials of the departmental archive of the Zaporizhstal' plant, which were dated to the late $40 \mathrm{~s}$ - early $50 \mathrm{~s}$ of the twentieth century. Thanks to the analysis of the current documentation of the metallurgical plant's office, the principles of staffing the plant during the first decade after the end of the Second World War, during the reconstruction, were reconstructed. The shortage of workers was acutely felt at the enterprise, as the use of machinery and mechanization of the restored works were used only on a small scale. Attracting a sufficient number of low-paid workers was the key to the recovery of the industry. Consideration of production situations and life conflicts at the micro-historical level allowed to reproduce the most standard methods used by the plant management to attract and retain workers. Some employees of the Zaporizhstal' plant were recruited on a freelance basis. The factory also tried to hide people who were hiding from the authorities in their previous places of residence. Lack of staff forced former criminals to be recruited legally. Forced labor played an important role in attracting staff to Zaporizhstal'. Voluntary methods repeated the repressive practices common in Stalin's time. It was forbidden to resign. Those who quit their jobs were tried and sentenced to 2 to 4 months in prison. Absenteeism was punishable by 6 months of correctional labor, deducting $25 \%$ of earnings. The victims of forced personnel policy were orphaned teenagers who were forcibly sent to the plant. The plant also used the temporary involvement of schoolchildren, students and residents of Zaporizhzhia for free performance of low-skilled work at the enterprise. 
В українській історичній науці за три останніх десятки років в основному успішно подолані наслідки компартійних заборон і в минулому нашої країни закрито багато лакун та білих плям. В рамках подальшого розвитку на основі нових підходів та методик розгортається переосмислення багатьох раніше пропагандистські міфологізованих радянською історичною наукою тем. В тому числі й історії окремих промислових підприємств.

В даному випадку досліджуватиметься історія одного $з$ найбільш важливих та знакових підприємств Запоріжжя - «Запоріжсталі», зведення якого в 30-ті роки XX ст. ознаменувало перетворення загубленого в південних степах містечка Олександрівськ в потужний промисловий центр Запоріжжя. В той же час вивчення історії металургійного комбінату передбачається на основі нових для української історичної науки підходів, крізь призму мікроісторичних досліджень, через вивчення життя та побуту конкретних осіб, що забезпечить саме людський вимір результатів нашої роботи.

Слід зазначити, що якщо нещадна експлуатація комуністичними проводирями СРСР українського селянства в та його безправність вже вивчається кілька десятків років, то становище промислових робітників в сталінську добу лише останнім часом починає знаходити своїх дослідників. В зв'язку 3 чим вивчення головних принципів залучення на відбудову заводу «Запоріжсталь» робочої сили i $€$ пріоритетом даної розвідки. Звертаємо увагу на те, що окремі аспекти проблеми, а саме - примусове утримання робітників на даному металургійному підприємстві - вже було розглянуто нами у попередніх розвідках ${ }^{1}$.

Часові рамки дослідження, 40-ві та початок 50-х pp. XX ст., були важливим етапом в історії СРСР. Це був час коли після завершення Другої світової війни радянська імперія перейшла до мирного будівництва та відновлення своєї економіки.

Базується ж робота на документах, переважно на додатках до особистих справ працівників заводу, час зберігання котрих в заводському архіві минув і які в свій час були передані металургійним комбінатом Запорізькому відділенню Інституту української археографії та джерелознавства, які були зведені в фонд № 1378 (номер фонду тотожній номерам фондів поточного архіву «Запоріжсталі» і фонду постійного зберігання його

\footnotetext{
${ }^{1}$ Подлужний А. Матеріали особових справ робітників «Запоріжсталі» про їх примусове утримання на заводі (1945 1955 рр.) // Scriptorium nostrum. Електронний історичний журнал / голов. ред. В. Андрєєв. Херсон, 2019. Вип. 1 (12). С. 222-231.
}

документів у Державному архіві Запорізької області) і зберігаються в Рукописному відділі (РВЗВІУАД).

На жаль, в радянський час будь які дослідження примусової мотивації працівників в ході повоєнного відновлення СРСР були неможливі, оскільки всі успіхи у відбудові промисловості, у відповідності 3 пропагандистськими кліше, обумовлювались керівною роллю компартії та трудовим героїзмом трудящих. I ситуація, коли із поруйнованих війною та збезлюділих колгоспів примусово забирали працівників на відбудову «Запоріжсталі» подавалась досить бравурно: «Незважаючи на гостру нестачу робочих рук в селі, колгоспи та радгоспи багатьох районів виділяли бригади до кінця відновлення першої черги заводу»².

Після здобуття ж незалежності українська історична наука почала досліджувати і позаекономічний примус щодо робітництва СРСР. В цьому плані слід відзначити ґрунтовну монографію М.Лободи «Трудові ресурси у важкій промисловості України під час нацистської окупації та у відбудовний період (1941-1950)», в якій частина другого розділу і присвячена саме вивченню використання примусової праці у важкій промисловості ${ }^{3}$.

В ще одній сучасній роботі, в якій досліджуються відбудова промисловості Півдня України, навіть після ознайомлення з державною політикою використання примусової праці в СРСР автор робить парадоксальний висновок, що сотні тисяч простих робітників «... незважаючи на важкі умови праці з великим піднесенням та ентузіазмом піднімали з руїн свій край»4.

В зв'язку з чим головним завданням даної роботи i $\epsilon$ визначення основних засад комплекту-

\footnotetext{
${ }^{2}$ Горячее дыхание : Краткий очерк истории Запорожского ордена Ленина и ордена Октябрьской Революции металлургического завода «Запорожсталь» им. Серго Орджоникидзе / Омельяненко П. Д., Ребро П. П., Репин В. Б., Мокрозуб 0. К.; Ред. кол. Герасименко А. А. и др. 2-е изд. перераб. и доп. Днепропетровск : Промінь, 1984. 120 с. С.65; «Запорожсталь» : Краткий очерк истории Запорож. ордена Ленина и ордена Октябрьской революции металлург. завода «Запорожсталь» им. Серго Орджоникидзе - предприятия коммунистического труда / [авт.: Омельяненко П. Д., Репин В. Б., Веретельник И. В. и др.]. Днепропетровск : Промінь, 1973. С.109.

${ }^{3}$ Лобода М. К. Трудові ресурси у важкій промисловості України під час нацистської окупації та у відбудовний період (1941-1950) / Наук. ред. 0. Лисенко. НАН України. Інститут історії України. К.: Інститут історії України, 2012. 206 с.

${ }^{4}$ Кислинська С.А. Відбудова промисловості Півдня України в період першої повоєнної п'ятирічки // Науковий вісник Миколаївського національного університету імені В. 0. Сухомлинського. 2014. № 3.37 (105). С.89.
} 
вання робітниками металургійного заводу крізь призму їхніх особистих доль. Також будуть досліджені не пропагандистські, а реальні способи мотивації працівників «Запоріжсталі». Це дозволить нам визначити обсяг прав радянського робітничого класу, офіційно проголошеного гегемоном і класовою базою тогочасної комуністичної держави та спростувати деякі пропагандистські міфи, які побутували в СРСР з часів тоталітаризму.

Важливим фактором, який прямо впливав на організацію залучення робочої сили, був обсяг завдань по відновленню запорізького промислового комплексу. Після зайняття Запоріжжя Червоною армією в жовтні 1943 р. постало завдання відновлення заводів промислового вузла, які лежали в руїнах після подвійного знищення, якому їх піддали. В 1941 р. їх похапцем руйнували перед відступом з міста радянських військ, а в 1943 р. гітлерівці знищували вже все, що тільки було можна. Одним з найбільш важливих підприємств, яке зазнало руйнувань та потребувало відновлення і був металургійний завод «Запоріжсталь», котрий в історії Запоріжжя був одним 3 найбільш важливих містоутворюючих підприємств.

Умови, в яких відбувалось відновлення запорізької промисловості. в тому числі і в Запоріжжі, були несприятливими. Продовжувалась війна, в СРСР не вистачало продуктів харчування, одягу, взуття, житла, меблів тощо. Це обумовлювало важкі умови життя радянського робітництва, включаючи й запоріжсталівців.

Хоча в країні і бракувало будівельних матеріалів, але влада для відновлення промисловості їх знаходила. Проте їхній дефіцит не міг не відбиватись і на відновлюваних роботах викликаючи простої. Накладаючись на невисоку кваліфікацію радянських управлінських кадрів в промисловості, які були неспроможні організувати ритмічні відновлювані роботи, це породжувало численні простої та штурмівщину.

Найбільш же гостро відчувалась нестача робітників, оскільки людські ресурси в першу чергу спрямовувались на фронт де і нищились в боях. Використання техніки, механізація відновлюваних робіт застосовувались лише в незначних масштабах. Натомість, особливо на першому етапі відновлення заводів, передбачалось використання в значних обсягах малокваліфікованої ручної праці. Малооплачуваної навіть по радянським міркам праці, яка потребувала значних фізичних зусиль. В зв'язку з чим залучення достатньої кількості працівників було тоді запорукою відновлення промислових підприємств. Крім того, завдяки широкому використанню малооплачуваної праці радянська держава суттєво зменшувала видатки на відновлення промислових підприємств.

Природно, що частина працівників на завод «Запоріжсталь» залучалась на основі вільного найму. Саме таким був випадок з уродженцем Полтавщини Нестеренком Демидом Демидовичем, який влітку 1947 р. влаштувався працювати на завод. Колишній льотчик-винищувач він в 1941 р. був збитий в бою і потрапив в полон. 3 полону в квітні 1942 року втік з групою і приєднався до партизанів. В подальшому Нестеренко, вірогідно після фільтраційних заходів, брав участь в боях в складі 48 ОШИСБ. В особовій справі він не розшифрував назву цього підрозділу, але можна припустити, що це 48 окремий штурмовий інженерно-саперний батальйон. У всякому випадку, вірогідно, зважаючи на перебування його в полоні, до літаків тоді Нестеренка не допустили.

В січні 1944 р. він отримав важке поранення. Змив кров'ю, як тоді говорили, вину за полон. 3 березня 1944 р. після одужання служив льотчиком в 10 запасному полку. В лютому 1946 р. був звільнений в запас. В вересні цього ж року він влаштувався військовим керівником в школу в селі Нова Чернещина на Харківщині. Проте вже у листопаді він звільнився і виїхав в Запоріжжя. Вірогідно, що голод 1946-1947 рр. прогнав колишнього офіцера з села і спрямував на завод. Тим більше, що початкова технічна вища освіта, досвід командування дали йому можливість не тільки уникнути малокваліфікованої праці, а й зробити невелику кар'єру на підприємстві. Спочатку він влаштувався в ремонтно-механічний цех бригадиром, а потім став майстром 5 .

Також на заводі намагались сховатись особи, які переховувались від влади. Саме так сталося з Кабальським Віктором Прокоповичем. У відповідь на запит заводу Військовий трибунал Запорізького гарнізону поінформував відділ кадрів «Запоріжсталі» про долю колишнього їхнього робітника Кабальського Віктора Прокоповича, він же Вовчук Віктор Прокопович, він же Крайнєв Віктор Миколайович. 5 жовтня 1949 р. цей трибунал засудив його до 10 років таборів за частиною 7, пункт «Г» статті 193 Кримінального кодексу РРФСР. 193 стаття встановлювала покарання за дезертирство. В пункті «г» частини сьомої цієї статі призначалось покарання за самовільну відлучку тривалістю більше доби для рядового та молодшого командного складу. Якщо ж зважити на фальшиві прізвища, які використовував Bi-

\footnotetext{
${ }^{5}$ РВЗВІУАД. Ф. 1378. 0п. 1-А. Спр. 6. Арк. 1-4.
} 
ктор Кабальський , то він явно переховувався від арешту ${ }^{6}$.

Нестача кадрів була така гостра, що на завод брали кримінальних злочинців, які відбули покарання. Свідченням цього були довідки про звільнення злодіїв, які відбули покарання, які зберігались в архіві заводу. Зокрема довідки засуджених за крадіжки 15-річного Соляного Віктора Денисовича та двадцятирічного Большухіна Миколи Григоровича ${ }^{7}$.

Проте і примусова праця в кінці 40-х та на початку 50-х років займала важливе місце в залученні кадрів на «Запоріжсталь». Слід зазначити, що багато в чому саме особливості радянської економіки визначали головні тенденції у залученні робочої сили і на цей завод, і на інші промислові підприємства. Після завершення колективізації та індустріалізації в її основних масштабах, сформована комуністична модель економіки виявилась неспроможною функціонувати без використання примусу. Ще в мирному 1940 р. Президія Верховної Ради СРСР прийняла ряд указів, які суттєво обмежили права промислових робітників. Одним 3 таких документів був Указ від 26 червня 1940 р. «Про перехід на восьмигодинний робочий день та семиденний робочий тиждень $і$ про заборону самовільного уходу робітників та службовців з підприємств і установ». У відповідності з цим документом робочий день збільшувався на годину (до семи та восьми годин). Неповнолітні, які досягли 16 років, та всі службовці стали працювати на 2 години більше - по вісім годин. Був встановлений один вихідний - неділя.

Звільнятись було заборонено. Лише керівник підприємства міг звільнити з роботи тих, хто йшов на пенсію, хто по хворобі чи по інвалідності не міг працювати. Ще можна було звільняти тих, хто поступив вчитися у вищі та середні спеціалізовані навчальні заклади.

Тих, хто самовільно кидав роботу судили і карали тюремним ув'язненням від двох до чотирьох місяців. За прогул суди карали шестимісячними виправними роботами 3 вираховуванням $25 \%$ заробітку. Керівників, які не притягували до відповідальності прогульників та тих, хто кинув роботу, теж мали судити ${ }^{8}$.

2 жовтня був прийнятий Указ «Про державні трудові резерви СРСР». У відповідності з ним

${ }^{6}$ РВЗВІУАД. Ф. 1378. 0п. 1-А. Спр. 19. Арк.1 - 3.

7 РВЗВІУАД. Ф. 1378. 0п. 1-А. Спр. 5. Арк.1а-1зв; Спр.10. Арк.1а-1зв.

8 Сборник законов СССР и указов Президиума Верховного совета СССР. 1938-1944 гг. Москва: Ведомости Верховного совета СССР, 1945. С.141-142. підлягали мобілізації від 800 тисяч до мільйона хлопців 14-15 та 16-17 років, які мали навчатись в ремісничих училищах та в школах фабрично-заводського навчання 3 шестимісячним та дворічним терміном навчання. Після завершення навчання вони вважались мобілізованими і мали відпрацювати на підприємстві чотири роки

Указ від 19 жовтня 1940 р. «Про порядок обов'язкового переведення інженерів, техніків, майстрів, службовців та кваліфікованих робітників з одних підприємств та установ в інші» поставив крапку в запровадженні фактично кріпацтва в промисловості ${ }^{10}$. Паралельно 3 цими указами, які регулювали рух робочої сили Укази від 10 липня та 10 серпня 1940 р. вводили кримінальну відповідальність за випуск недоброякісної продукції (5-8 років позбавлення волі) та покарання за дрібні крадіжки і хуліганство на виробництві (1 рік позбавлення волі $)^{11}$.

Вже під час війни антиробітниче законодавство СРСР ще посилилось. 26 червня 1941 р. Указ Президії Верховної Ради СРСР дозволив керівникам підприємств щоденно залучати працівників до позаурочних робіт тривалістю до трьох годин. Також скасовувались чергові та додаткові відпустки. Виплата ж грошової компенсації за них відтерміновувалась до закінчення війни ${ }^{12}$. Фактично цим указом в СРСР був офіційно запроваджений 11-годинний робочий день. Якщо ж врахувати не оплачуваний час, потрібний на перезміни, прибирання робочого місця після роботи тощо, то фактично робітники тоді працювали фактично по 12 годин. Більше того, при потребі заводська адміністрація могла змусити робітників виконувати роботу ледь не цілодобово. 26 грудня 1941 р. Указ «Про відповідальність робітників і службовців підприємств військової промисловості за самовільне покидання підприємств» ще більше посилив відповідальність за самовільне звільнення 3 роботи. Ним заборонялось працівникам оборонних заводів та інших підприємств, які постачали їм комплектуючі, звільнятись з роботи. Порушників Указу, як дезертирів, судили військові трибунали, які призначали за цей «злочин» від 5 до 8 років позбавлення волі ${ }^{13}$ ! У 1942 р., Указом від 29 вересня, мобілізованими вважались всі робітники та службовці на підприємствах наближених до фронту ${ }^{14}$. Хоча в 1945 р. були скасовані обов'яз-

\footnotetext{
${ }^{9}$ Там само. С.139-141.

${ }^{10}$ Там само. С.144-145.

${ }^{11}$ Там само. С. 241-242, 244.

${ }^{12}$ Там само. С.143-144.

${ }^{13}$ Там само. С.247-248.

14 Там само. С.146-147.
} 
кові позаурочні роботи та поновлено надання відпусток працівникам, проте інші укази 1940 р. продовжували діяти до 1956 р.! Це дозволяло адміністрації «Запоріжсталі» широко застосовувати примус в своїй кадровій політиці.

Вірогідно, що під час війни одною з найлегших форм примусового залучення працівників до роботи на заводі було відкликання кваліфікованих робітників, котрі були мобілізовані в Червону Армію, оскільки це рятувало їх від перспективи загинути в боях. Саме так сталося з Мельниченком Пилипом Тимофійовичем. Хоч він і був трактористом, але в 1932 р. під час голодомору покинув село і завербувався на спорудження «Дніпрогесу». Потім працював на «Дніпроспецсталі», верстатником на заводі «№29». В окупації працював вантажником, молотобійцем, чорноробом. В 1943 р. під час німецької евакуації Запоріжжя сховався в руїнах «Запоріжсталі» і дочекався Червоної армії. Добровільно пішов служити у військо. Проте ще під час війни був відкликаний на завод і 17 травня 1945 р. вже був на заводі ${ }^{15}$.

Частину працівників примусово набирали 3 поруйнованих повоєнних колгоспів, які задихались від браку робочих рук. Саме так сталося 3 Клопотнюком Іваном Петровичем. Мешканець Вінницької області він працював на відновленні «Запоріжсталі» 31946 р.. В зв'язку з хворобою матері просив звільнити його 3 «Запоріжсталі», але його продовжували утримувати на заводі. Просто не звільняли з роботи. Покинути ж роботу він не міг. 30.05.1949 р. Клопотнюк Іван Петрович звернувся з листом до члена ЦК, Політбюро та Оргбюро КП(б)У М.С.Хрущова, в якому скаржився, що його не відпускають 3 «Запоріжсталі» додому до хворої матері попри його багаторазові відповідні звернення до заводської адміністрації. Справу було взяти під контроль Особливий Сектор ЦК КП(б)У переслав його звернення на завод «Запоріжсталь» і взяв справу на контроль. В результаті керівництво заводу дозволило Івану Клопотнюку розрахуватись ${ }^{16}$.

I такі звернення до М.С.Хрущова були не поодинокими, оскільки заводська адміністрація настільки звикла до підневільної праці робітників, що навіть в середині 50-х рр. XX століття ще чинила перепони їхньому звільненню. Підневільні ж робітники намагались використати будь-який шанс, щоб вирватись з заводу. Кампанія освоєння цілинних земель, котра супроводжувалась пропагандистським галасом, стала одною 3 таких мож-

${ }_{15}$ РВЗВІУАД. Ф. 1378. 0п. 1-А. Спр. 3. Арк. 1а.

${ }^{16}$ РВЗВІУАД. Ф. 1378. 0п. 1-А. Спр. 18. Арк. 1- 2. ливостей. 21 грудня 1954 р., запоріжсталівець Лукоянов С.І.,. вже перебуваючи на цілині, написав до М.С.Хрущова, який вже був секретарем ЦК КПРС, що заводська адміністрація не видає його документи. В 1955 р. колишній дітдомівець Македонський Г.А., якого попри його волю прикріпили до Запоріжсталі, теж звернувся до М.С.Хрущова, що його не відпускають «на цілину» ${ }^{17}$.

Якщо ж такий підневільний робітник самовільно кидав роботу, то його судили. Саме так сталося 3 двадцятирічним Баздирєвим Віктором Михайловичем, уродженцем села Михайлівки Михайлівського району, який 5 травня 1948 р. був засуджений Військовим трибуналом військ Запорізької області до 5 років позбавлення волі за Указом Президії Верховної Ради СРСР від 26 грудня 1941 р. (самовільне залишення роботи на підприємствах військової промисловості). Проте за іншим указом, від 31 травня 1948 р. був звільнений від покарання і примусово відправлений на роботи в промисловості в Великий Токмак. Проте туди він не доїхав, а опинився на «Запоріжсталі» ${ }^{18}$.

Однією із жертв такої кадрової політики були діти. Особливо беззахисними були діти-сироти, які не мали підтримки від батьків, $і$ яких направляли працювати на заводи, в тому числі i «Запоріжсталь». Характерною була доля Дінчевої Валентини Кирилівни з села Гамівки Приазовського району. 13-річна дитина 22 листопада 1947 р. звернулась в дитячу кімнату Міського відділу МВC Мелітополя і заявила, що ї̈ батьки померли. Причина смерті її батьків в документі не була вказана, проте, вірогідно, померли вони від голоду. В 1947 р. в Україні одна епідемія викошувала родини - голод. Помічник інспектора дитячої кімнати Суслова склала постанову про відправлення Дінчевої, як бездоглядної, в дитячий приймальник-розподільник Міського відділу МВС Мелітополя. Зважаючи ж на те, що ця постанова опинилась в архіві «Запоріжсталі», то навряд чи цю дівчинку довго тримали в розподільнику, а просто транзитом через розподільних відправили на завод працювати ${ }^{19}$.

Зважаючи на відсутність життєвого досвіду у сиріт та їхю беззахисність заводське керівництво намагалось їх використати на найменш оплачуваних роботах, на яких ніхто 3 дорослих не погоджувався працювати. Про це свідчить пояснювальна записка від малолітнього працівника «Запоріжсталі» Некрасова В.I. начальнику

\footnotetext{
17 РВЗВІУАД. Ф. 1378. 0п. 1-Б. Спр. 33. Арк.1; Спр. 34. Арк.1-3. ${ }_{18}^{18}$ РВЗВІУАД. Ф. 1378. 0п. 1-А. Спр. 11. Арк.1.

${ }^{19}$ РВЗВІУАД. Ф. 1378. 0п. 1-А. Спр. 8. Арк.1.
} 
відділу кадрів підприємства. В ній він пояснив, що в квітні 1953 р. був влаштований на завод 3 дитячого приймальника, а в травні розрахувався за власним бажанням і подер трудову книжку. В липні того ж року дитячий приймальник знов направив його на «Запоріжсталь», а з відділу кадрів відправили працювати на те ж саме місце, з якого він звільнився. I Некрасову довелось змиритись і навіть просити видати йому нову трудову книжку ${ }^{20}$.

Цікавим документом, який засвідчує подвійне примусове залучення кадрів на промислові підприємства, є заява мешканки одного з сіл Запорізької області Тихонюк Ніни Семенівни. 08.01.1945 р. вона звернулась із заявою до директора запорізького ремісничого училища №5 Восновського 3 проханням виключити 3 навчального закладу її брата Володимира. Ї̈̈, як керівника комсомольської організації колгоспу разом 3 іншими комсомольцями відправляли на 3 місяці «на Донбас», на відновлення зруйнованих шахт та промислових підприємств. В зв'язку з чим їй не було на кого залишити житло та господарство. Вірогідно, вона планувала залишити на господарстві брата. На їі заяві директор училища наклав резолюцію: «В особову справу», що означало відмову. Адже це було училище, яке готувало робітників для відновлення запорізьких заводів. При цьому учні училища вважались мобілізованими ${ }^{21}$. Якщо 6 директор відпустив такого учня, то, у відповідності з трудовими сталінськими указами він відповідав би за це. Ну, а Ніна Семенівна була зобов'язана погоджуватись на будь-які роботи не тільки як комсомолка, а й керівниця сільської комсомольської організації.

Слід зазначити, що дехто з підлітків, ризикуючи отримати тюремний строк, кидав роботу та втікав з заводу ${ }^{22}$. Не маючи кваліфікації, призначені виконувати важку та малооплачувану роботу, відірвані від родин, не маючи змоги організувати свій побут вони голодували. Якогось іншого шансу хоч трохи змінити свою долю у них не було. I попри ризик нелюдськи суворого покарання за намагання поліпшити своє життя діти втікали 3 заводу. Це траплялось настільки часто, що адміністрація «Запоріжсталі» навіть замовила спеціальні друковані бланки, щоб повідомляти родичів втікачів про зникнення підлітків з заводу 23.

Поруч із постійною експлуатацією підлітків

20 РВЗВІУАД. Ф. 1378. 0п. 1-Б. Спр. 22. Арк.1.

${ }_{21}$ РВЗВТУАД. Ф. 1378. 0п. 1-А. Спр. 4. Арк.1.

22 РВЗВІУАД. Ф. 1378. 0п. 2-Б. Спр. 22. Арк. 1-3.

${ }^{23}$ РВ ЗВ ІУАД. Ф. 1378. 0п. 2-Б. Спр. 22. Арк. 1-3. використовували на заводі і традиційну практику тимчасового залучення школярів, студентів та мешканців Запоріжжя до безкоштовного виконання якихось малокваліфікованих робіт на підприємстві. Працівників «Запоріжсталі» добровільно-примусово змусили безкоштовно відпрацювати по тридцять годин в їхній неробочий час на відбудові заводу. Потім цю практику поширили і на мешканців і міста, і прилеглих сільських районів, які теж у свій вільний час працювали на заводській будові ${ }^{24}$.

Таким чином, можна зазначити, що 3 початку 40-х рр. і до другої половини 50-х рр. XX ст. в СРСР і в промисловості було обмежене, а потім і суттєво згорнуте використання вільнонайманої праці, а робітники були позбавлені елементарних трудових прав і перетворились в залежний прошарок населення. Відновлення «Запоріжсталі», яка існувала в радянській парадигмі виробничих відносин, відбувалось значною мірою за рахунок примусової праці різних категорій населення. Так званий «трудовий ентузіазм» таких робітників-невільників, був пропагандистським комуністичним шумовинням, яке маскувало репресивну основу радянської промисловості.

\footnotetext{
${ }^{24}$ Горячее дыхание : Краткий очерк истории Запорожского ордена Ленина и ордена Октябрьской Революции металлургического завода «Запорожсталь» ... С.64; «Запорожсталь» : Краткий очерк истории ... С.108-109; . Запорожсталь. Симфония Металла : [70 лет. Годы. События. Люди] / авт.-сост. Н. Кузьменко, Н. Михайлов. Запорожье : Тандем-У, 2003. С.65.
} 


\section{References}

«Zaporozhstal»: Kratkyi ocherk istorii Zaporozh. ordena Lenina i ordena Oktiabrskoy revoliutsii metallurh. zavoda «Zaporozhstal'» im. Serho Ordzhonikidze - predpryiatiya kommunisticheskogo truda / [avt.: Omelianenko P. D., Repyn V. B., Veretel'nik Y. V. i dr.]. Dnepropetrovsk: Promin', 1973. 255 s.

Gorjachee dykhanie : Kratkiy ocherk istorii Zaporozhskogo ordena Lenina i ordena Oktiabrskoy Revoliutsii metallurgycheskogo zavoda «Zaporozhstal'» im. Sergo Ordzhonikidze / Omelianenko P. D., Rebro P. P., Repin V. B., Mokrozub 0. K.; Red. kol. Gerasymenko A. A. i dr. 2-e yzd. pererab. y dop. Dnepropetrovsk : Promin', 1984. 120 s.

Kyslynska S.A. Vidbudova promyslovosti Pivdnia Ukrainy v period pershoi povoiennoi piatyrichky // Naukovyi visnyk Mykolaivskoho natsionalnoho universytetu imeni V. 0. Sukhomlynskoho. 2014. № 3.37 (105). S. 86-89.

Loboda M. K. Trudovi resursy u vazhkii promyslovosti Ukrainy pid chas natsystskoi okupatsii ta u vidbudovnyi period (1941-1950) / Nauk. red. 0. Lysenko. NAN Ukrainy. Instytut istorii Ukrainy. K. : Instytut istorii Ukrainy, 2012. 206 s.

Podluzhnyi A. Materialy osobovykh sprav robitnykiv «Zaporizhstali» pro yikh prymusove utrymannia na zavodi (1945

- 1955 rr.) // Scriptorium nostrum. Elektronnyi istorychnyi zhurnal / holov. red. V. Andrieiev. Kherson, 2019. Vyp. 1 (12). S. 222-231.

Rukopysnyi viddil Zaporizkoho viddilennia Instytutu ukrainskoi arkheohrafii ta dzhereloznavstva im. M.S. Hrushevskoho NAN Ukrainy (RVZVIUAD). F. 1378. Op. 1-A (Materialy z sotsialnoi istorii. 1940-i roky).

RVZVIUAD. F. 1378. Op. 1-B (Materialy z sotsialnoi istorii. 1950-i roky).

RVZVIUAD. F. 1378. Op. 2-B (Kolektsiia dokumentiv. 1940-i roky).

Sbornik zakonov SSSR i ukazov Prezidiuma Verkhovnogo soveta SSSR. 1938-1944 gg. M. : Vedomosti Verkhovnogo soveta SSSR, 1945. $362 \mathrm{~s}$.

Zaporozhstal. Symfoniya Metalla : [70 let. Gody. Sobytyia. Liudi] / avt.-sost. N. Kuzmenko, N. Mykhailov. Zaporozhje : Tandem-U, 2003. $448 \mathrm{~s}$. 